\title{
MICROBIOLOGICAL ANALYSIS OF SECONDARY BACTERIAL INFECTIONS IN PATIENTS INFECTED WITH THE SARS-COV-2 VIRUS
}

\author{
Melek BILGİN ${ }^{*}$, Eşe BAŞBULUT ${ }^{1}$, Hacer IșLER ${ }^{1}$, Cemanur AYGÜN² \\ ${ }^{1}$ Medical Microbiology Department, Samsun Training and Research Hospital, Health Science University, 55090, Samsun, Turkey \\ ${ }_{2}^{2}$ Infection Disease and Clinical Microbiology Department, Samsun Training and Research Hospital, Health Science University, 55090, \\ Samsun, Turkey
}

\begin{abstract}
Accumulating evidence shows that secondary infection increases the risk of disease severity in respiratory diseases. There have been few studies about secondary infections among COVID-19 patients. Therefore we aimed to investigate prevalence, predisposing factors and causative organisms associated with COVID-19 secondary infection. This study was conducted at Training and Research Hospital in Samsun Turkey between March 15, 2020 and June 15, 2020. Hospitalized COVID-19 patients confirmed with Reverse Transcription Polymerase Chain Reaction (RT-PCR) were included in this study. Various clinical specimens (urine, sputum, endotracheal aspirate, blood etc.) of these patients have been sent to the microbiology laboratory were evaluated retrospectively. During the study period, 270 patients have been diagnosed COVID-19 confirmed with PCR. The bacterial secondary infection rate among COVID-19 patients was $4 \%$ (11 of 270). The mortality rate among intensive care unit (ICU) patients with secondary infections was $80 \%$. The most common secondary infection was urinary tract infection followed by bacteremia, and pneumonia. The most common isolated bacteria is Escherichia coli (E. coli) followed by coagulase-negative staphylococci (CoNS). Among COVID-19 patients, secondary infection may significantly inhibit the immune system of host and leads to significant morbidity and mortality. This is problematic and especially impacts patient clinical management, infection control, and antimicrobial stewardship programs. Therefore, further studies are needed to identify the possible pathogens and to evaluate the influence of secondary infections on the severity of SARS-CoV-2 infection.
\end{abstract}

Keywords: COVID-19, SARS-CoV-2, Secondary infection

*Corresponding author: Medical Microbiology Department, Samsun Training and Research Hospital, Health Science University, 55090, Samsun, Turkey

E mail: drmelekbilgin@gmail.com (M BíLGiN)

Melek BiLGíN (iD) https://orcid.org/0000-0003-0025-8717

Eșe BAȘBULUT (iD) https://orcid.org/0000-0001-8235-9524

Hacer İȘLER (iD) https://orcid.org/0000-0002-0722-8425

Received: January 23, 2021

Accepted: June 17, 2021

Published: September 01, 2021

Cemanur AYGÜN (iD) https://orcid.org/0000-0001-5295-746X

Cite as: Bilgin M, Başbulut E, İşler H, Aygün C. 2021. Microbiological analysis of secondary bacterial infections in patients infected with the SARS-COV-2 virus. BSJ Health Sci, 4(3): 270-273.

\section{Introduction}

The coronavirus disease 2019 (COVID-19) was first recognized in Wuhan, China, in December 2019, it rapidly spread across mainland China and became a global threat (WHO, 2020). A striking aspect of COVID-19 is that the disease became a pandemic in less than 3 months (Chen et al., 2020). The first diagnosed patient in Turkey has been reported by the Republic of Turkey Ministry of Health on March 11, 2020. As of July 20, 2020, over two hundred twenty thousand cases in Turkey, and fourteen million cases around the world have been declared (Turkey Ministry of Health COVID-19 guide 2020).

The novel coronavirus is now referred to as severe and critical acute respiratory syndrome coronavirus-2 (SARSCoV-2) by the International Committee on Taxonomy of Viruses (ICTV) (Bosseboeuf, 2018). SARS-CoV-2, a novel enveloped RNA betacoronavirus, has phylogenetic similarity to severe acute respiratory syndrome coronavirus (SARS) and Middle East respiratory syndrome coronavirus (MERS) (Fu et al., 2019).
Secondary and co-infection has been reported in patients with severe SARS and MERS, but there is limited knowledge on secondary infection among patients with COVID-19 (Li and Zhou, 2013).

A low proportion of COVID-19 patients have secondary bacterial infections less than in previous influenza pandemics but secondary bacterial infection leads to significant morbidity and mortality (Zhu et al., 2020). This is problematic and significantly impacts patient clinical management, infection control, and antimicrobial stewardship programs (Zhou et al., 2020, Wang et al., 2019). Therefore we aimed to investigate prevalence, risk-factors, characteristics, aetiological agents associated with COVID-19 secondary infections.

\section{Materials and Methods}

The study was conducted at Training and Research Hospital in Samsun Turkey between March 15, 2020 and June 15, 2020. Hospitalized patients with confirmed COVID-19 were included in this study if they fulfilled two 
primary criteria: 1) age >18 years; 2) SARS-CoV-2 nucleic acid was detected by real-time PCR to confirm the virus infection. The patient management was carried out according to the "COVID-19 Diagnosis and Treatment Guide" released by the Turkish Ministry of Health (Turkey Ministry of Health COVID-19 guide 2020).

Various clinical specimens (urine, sputum, endotracheal aspirat, blood etc.) of these patients that have been sent to the microbiology laboratory were evaluated retrospectively. Received samples were inoculated on to $5 \%$ sheep blood agar (Becton Dickinson $\mathrm{GmbH}$, Germany) and Eosin Methylen-blue agar (EMB) (Becton Dickinson GmbH, Germany) and incubated for $24 \mathrm{~h}$ at 37 ${ }^{\circ} \mathrm{C}$. Blood culture samples were analyzed using fully automated blood culture system (Render BC128, China). The identification and antimicrobial susceptibility of isolated strains was performed by using VITEK-2 (bioMérieux, France) automatised systems. Epidemiological, demographic, clinical, treatment and outcome data were obtained from medical records.

\section{Results}

During the study period, 270 patients have been diagnosed COVID-19 confirmed with PCR in Samsun Training and Research Hospital. Among these patients $14.4 \%$ (39 of 270 ) were in intensive care unit (ICU), $85.5 \%$ (231 of 270 ) were non ICU. 84 various clinical samples from Covid-19 (+) patients have been sent to microbiology laboratory for culture and 12 (\%14.28) samples were positive for bacterial or fungal growth. Of 12 strains; 5 were isolated from urine, 4 were from blood and 3 were from endotracheal aspirat. The secondary infection rate among COVID-19 patients was 4\% (11 of 270). Among these patients 6 were female and 5 were male; the median age was 71.6 years in ICU, 55 years in non ICU patients. The median lenght of hospitalization was 23 days in ICU patients and 9 days in non ICU patients.

Among ICU patients 17 (43.5\%) of 39 died. The mortality rates among ICU patients with secondary infections and without secondary infections were $80 \%(4 / 5)$ and $38 \%$ $(13 / 34)$ respectively. The most common comorbidities were; chronic obstructive pulmonary disease, diabetes and cardiovascular disease and in ICU patients with secondary infections comorbidities were more than one. The most common secondary infection was urinary tract infection (45\%) followed by bacteremia (36\%), and pneumonia (27\%). The most common isolated bacteria is E.coli followed by CoNS. Characteristics of COVID-19 patients with secondary infections listed in Table 1.

\section{Discussion}

Other respiratory viruses, such as seasonal/pandemic influenza, MERS-CoV and SARS-CoV-1, show differing levels of bacterial/fungal secondary infection. Accumulating evidence demonstrated the important role of bacterial coinfection in the severity of respiratory diseases, but a few clinical studies have reported the outcome of secondary bacterial infection due to COVID19 (Blyth et al., 2013). In the present study we described for the first time the secondary bacterial infections among confirmed COVID-19 patients at Samsun Training and Research Hospital in Turkey.

Based on previous studies the prevalence of COVID-19 associated viral/bacterial/fungal secondary infections ranged from $1.0 \%$ to $45.0 \%$ (Lai et al., 2020). In their study, (Goyal and colleagues 2020) reported 19/338 $(6 \%)$ rate of bacterial/fungal co-infection during hospital admission but it is not clear whether these patients were in critical or non-critical care. In a different setting, Wang et al. 2020 conducted a retrospective study that included a cohort of 339 patients. The study showed that the most common complications in COVID-19 patients were bacterial infection (42.8\%). In our study; we observed the secondary bacterial infection rate among confirmed COVID-19 patients was 11/270 (4\%).

In a meta-analysis reported by Lansbury et al (2020), they evaluated thirty studies including 3834 patients; overall, $7 \%$ of hospitalized COVID-19 patients had a bacterial co-infection and a higher proportion of ICU patients had bacterial co-infections than patients in mixed ward/ICU settings. Like this report in our study we observed that secondary infection rate in ICU patients $(12.8 \%)$ was higher than in non ICU patients $(2.6 \%)$. Furthermore, the median lenght of hospitalization and the mortality rate was higher proportion in ICU patients with secondary infection.

In another study; Zhou and colleagues 2020; reported that in $28 / 191(15 \%)$ of patients had secondary bacterial infection admitted to hospitals in China, of these patients with secondary bacterial infection, 27/28 died. Lai et al. 2020 in their study established that the prevalence of secondary infections could be as high as 50\% among non-survivors among COVID-19 patients (Wu et al., 2020). In our study, we observed the mortality rate among COVID-19 patients with secondary infection was $4 / 11(36 \%)$ and all were ICU patients. However we considered that the mortality of COVID-19 ICU patients with secondary infection was (80\%) significantly higher than (38\%) that of COVID-19 ICU patients without secondary infection.

While COVID-19 by itself can cause acute respiratory decompensation, it is also important to consider all other sources of hospital acquired infections in these patients such as indwelling central venous catheters or urinary tract catheters (Zhu et al., 2020). Finally, a retrospective study of 918 COVID-19 patients conducted by He et al from Wuhan, China showed that the most common coinfections were pneumonia followed by bacteremia and urinary tract infection (He et al., 2020). But in our study, we observed the most secondary infection was urinary tract infections followed by bacteremia and pneumonia. We also noticed that using of devices increased the risk of secondary infections especially in elderly ICU patients.

Wang et al. (2020) and He et al. (2020) reported that 
secondary infections in patients with COVID-19 are caused by drug-resistant organisms. In our study we isolated Extended Spectrum Beta-laktamase (ESBL) positive E.coli, multi drug resistant P.aeruginosa, K.pneumoniae, E.faecium and CoN. Furthermore;
S.hominis and S.caprae evaluated as contamination and the others considered as nosocomial infections. These patients with CoNS isolated in their blood cultures were younger than 65 years and had no comorbid disease.

Table 1. Characteristics of confirmed COVID-19 Patients with Secondary Infections

\begin{tabular}{|c|c|c|c|c|c|c|c|}
\hline Patient & Sex/Age & ICU/dead & Sample & Pathogen & Comorbidities & Therapy & LHD \\
\hline 1 & $\mathrm{~F} / 70$ & No/No & Urine & P.aeruginosa & $\mathrm{HT}$ & $\begin{array}{l}\text { Covid thr* } \\
\text { Antiviral } \\
\text { Sefiksim }\end{array}$ & 18 day \\
\hline 2 & $\mathrm{~F} / 33$ & No/No & Urine & E.coli & None & Covid thv* & 6 day \\
\hline 3 & $\mathrm{M} / 48$ & No/No & Blood & S.epidermidis & Larynx CA & $\begin{array}{l}\text { Covid thr* } \\
\text { Favipravir }\end{array}$ & 8 day \\
\hline 4 & $\mathrm{~F} / 82$ & No/No & Urine & $\begin{array}{l}\text { E.coli } \\
(E S B L+)\end{array}$ & HT & $\begin{array}{l}\text { Covid thr* } \\
\text { Meropenem }\end{array}$ & 6 day \\
\hline 5 & $\mathrm{~F} / 48$ & No/No & Blood & S.hominis & None & Covid thr* & 8 day \\
\hline 6 & $\mathrm{M} / 50$ & No/No & Blood & S.caprae & None & Covid thr* & 7 day \\
\hline 7 & $\mathrm{M} / 67$ & Yes/Yes & $\begin{array}{l}\text { Endotracheal } \\
\text { aspirate }\end{array}$ & E.coli & $\begin{array}{l}\text { DM } \\
\text { HT }\end{array}$ & $\begin{array}{l}\text { Covid thr* } \\
\text { Vankomisin+ } \\
\text { Meropenem } \\
\text { Plasma }\end{array}$ & 14 day \\
\hline 8 & M/68 & Yes/Yes & $\begin{array}{l}\text { Endotracheal } \\
\text { aspirate }\end{array}$ & K.pneumonie & $\begin{array}{l}\text { CVD } \\
\text { COPD } \\
\text { DM }\end{array}$ & $\begin{array}{l}\text { Covid thr* } \\
\text { Meropenem } \\
\text { Levofloksasin } \\
\text { Plasma }\end{array}$ & 40 day \\
\hline 9 & $\mathrm{~F} / 67$ & Yes/Yes & $\begin{array}{l}\text { Endotracheal } \\
\text { aspirate } \\
\text { Urine }\end{array}$ & $\begin{array}{l}\text { E.coli } \\
\text { Candida sp. }\end{array}$ & $\begin{array}{l}\text { Obesite } \\
\text { HT }\end{array}$ & $\begin{array}{l}\text { Covid thr* } \\
\text { TZP } \\
\text { Candisept } \\
\text { Plasma }\end{array}$ & 22 day \\
\hline 10 & $\mathrm{M} / 79$ & Yes/No & Urine & E.faecium & $\begin{array}{l}\text { Congestive } \\
\text { heart failure } \\
\text { COPD } \\
\text { Alzhemier }\end{array}$ & $\begin{array}{l}\text { Covid thr* } \\
\text { Antiviral } \\
\text { TZP } \\
\text { Teikoplanin }\end{array}$ & 27 day \\
\hline 11 & $\mathrm{~F} / 77$ & Yes/Yes & Blood & S.epidermidis & $\begin{array}{l}\text { Congestive } \\
\text { heart failure } \\
\text { COPD } \\
\text { DM }\end{array}$ & $\begin{array}{l}\text { Covid thr* } \\
\text { Meropenem } \\
\text { Linezolid, } \\
\text { Plasma }\end{array}$ & 11 day \\
\hline
\end{tabular}

$\mathrm{LHD}=$ lenght of hospitalization days, $\mathrm{ICU}=$ intensive care unit, $\mathrm{HT}=$ hypertension, $\mathrm{COPD}=$ chronic obstructive pulmonary disease, $\mathrm{DM}=$ diabetes, Covid thr= hydroxychloroquine, azithromycin, $\mathrm{CVD}=$ cerebrovascular disease, $\mathrm{TZP}=$ piperasilin tazobaktam

Antimicrobials have several potential roles in the management of COVID-19. Experimental therapies for the treatment of SARS-COV-2 vary between countries (Hendaus \& Jomha 2020, Poschet et al., 2020). In our study, at the beginning of the study period levofloksasin was used, then azithromycin was used in COVID-19 patients according to the guideline released by Turkish Ministry of Health for empiric antimicrobial therapy. In previous studies; azithromycin has been shown to be active in vitro against Zika and Ebola viruses and to prevent severe respiratory tract infections when administrated to patients suffering viral infection (Retallack et al., 2016, Madrid et al., 2015, Bosseboeuf et al., 2018). Similar to this report; according to our secondary bacterial infections rate (4\%), we suggested that; for COVID-19 patients if co-bacterial infection cannot be ruled out, azithromycin maybe effective as empiric antimicrobial therapy for mild cases. The present report has a limitation that atypical bacteriyel pathogens (Mycoplasma pneumoniae and Legionella pneumophila) and viral pathogens were not included in this study.

\section{Conclusion}

Secondary infections might play a crucial role in the therapy of COVID-19 patients and leads to significant morbidity and mortality. Therefore, further studies are needed to identify the possible pathogens and to evaluate the influence of secondary infections on the severity of SARS-CoV-2 infection.

\section{Author Contributions}

MB; initiated the research idea, developed, organized, analyzed, interpreted the data, wrote the manuscript, structured the paper and edited the manuscript. EB and CA supervised the research. Hi; suggested the research methods.

\section{Conflict of Interest}

The authors declared that there is no conflict of interest. 


\section{Ethical Approval/Informed Consent}

The authors confirm that the ethical policies of the journal, as noted on the journal's author guidelines page, have been adhered to. This study was approved by the Ethics Commission of Samsun Training and Research Hospital (Approve number: 05.06.2020, 2020/8/8).

\section{Acknowledgments}

This study reported as oral presentation in COVID19 Symposium Online International- Multidisciplinary 26-28 June 2020 Turkey. The authors disclosed that they did not receive any grant during conduction or writing of this study.

\section{References}

Blyth CC, Webb SA, Kok J, Dwyer DE, van Hal SJ, Foo H, Ginn AN, Kesson AM, Seppelt I, Iredell JR, ANZIC Influenza Investigators, \& COSI Microbiological Investigators. 2013. The impact of bacterial and viral co-infection in severe influenza. Influenza Other Respir Viruses, 7(2): 168-176. https://doi.org/10.1111/j.1750-2659.2012.00360.x.

Bosseboeuf E, Aubry M, Nhan T, Jean Jacques de Pina JJ, Rolain JM, Raoult D, Musso D. 2018. Azithromycin inhibits the replication of Zika virus. J Antivirals Antiretrovir, 10(1): 6-11. DOI: $10.4172 / 1948-5964.1000173$.

Chen N, Zhou M, Dong X, Qu J, Gong F, Han Y, Qiu Y, Wang J, Liu Y, Wei Y, Xia J, Yu T, Zhang X, Zhang L. 2020. Epidemiological and clinical characteristics of 99 cases of 2019 novel coronavirus pneumonia in Wuhan China, a descriptive study. Lancet London England, 39510223: 507-513. https,//doi.org/10.1016/S0140-67362030211-7.

Fu L, Wang B, Yuan T, Chen X, Ao Y, Fitzpatrick T, Li P, Zhou Y, Lin YF, Duan Q, Luo G, Fan S, Lu Y, Feng A, Zhan Y, Liang B, Cai W, Zhang L, Du X, Li L, Zou H. 2020. Clinical characteristics of coronavirus disease 2019 COVID-19 in China, A systematic review and meta-analysis. J Infect, 806: 656-665. https,//doi.org/10.1016/j.jinf.2020.03.041.

Goyal P, Choi JJ, Pinheiro LC, Schenck EJ, Chen R, Jabri A, Satlin MJ, Campion TR, Jr Nahid M, Ringel JB, Hoffman KL, Alshak MN, Li HA, Wehmeyer GT, Rajan M, Reshetnyak E, Hupert N, Horn EM, Martinez FJ, Gulick RM, Safford MM. 2020. Clinical characteristics of Covid-19 in New York city. New England J Med, 38224: 2372-2374. https,//doi.org/10.1056/NEJMc2010419.

He Y, Li W, Wang Z, Chen H, Tian L, Liu D. 2020. Nosocomial infection among patients with COVID-19, a retrospective data analysis of 918 cases from a single center in Wuhan China. Infect Control Hospital Epid, 418: 982-983. https,//doi.org/10.1017/ice.2020.126.

Hendaus MA, Jomha FA. 2020. Covid-19 induced superimposed bacterial infectionJ of biomolecular structure dynamics 17Advance online publication. https,//doi.org/10.1080/07391102.2020.1772110 (accessed date July 10, 2020).
Lai CC, Wang CY, Hsueh PR. 2020. Co-infections among patients with COVID-19, The need for combination therapy with nonanti-SARS-CoV-2 agents? J Microbiol Immun Infect, 534: 505512. https,//doi.org/10.1016/j.jmii.2020.05.013.

Lansbury L, Lim B, Baskaran V, Lim WS. 2020. Co-infections in people with COVID-19, a systematic review and metaanalysis. J Infect, 812: 266-275 https,//doi.org/10.1016/j.jinf.2020.05.046.

Li XX, Zhou XN. 2013. Co-infection of tuberculosis and parasitic diseases in humans, a systematic review. Parasites Vectors, 6: 79. https,//doi.org/10.1186/1756-3305-6-79.

Madrid PB, Panchal RG, Warren TK, Shurtleff AC, Endsley AN, Green CE, Kolokoltsov A, Davey R, Manger ID, Gilfillan L, Bavari S, Tanga MJ. 2015. Evaluation of Ebola Virus Inhibitors for Drug Repurposing. ACS Infect Diseases, 17: 317-326. https,//doi.org/10.1021/acsinfecdis.5b00030

Poschet JF, Perkett EA, Timmins GS, Deretic V. 2020. Azithromycin and ciprofloxacin have a chloroquine-like effect on respiratory epithelial cells. bioRxiv, 2020.03.29.008631. https,//doi.org/10.1101/2020.03.29.008631.

Retallack H, Di Lullo E, Arias C, Knopp KA, Laurie MT, SandovalEspinosa C, Mancia Leon WR, Krencik R, Ullian EM, Spatazza J, Pollen AA, Mandel-Brehm C, Nowakowski TJ, Kriegstein AR, DeRisi JL. 2016. Zika virus cell tropism in the developing human brain and inhibition by azithromycin. Proceedings of the National Academy of Sciences of the United States of America, 11350: 14408-14413. https,//doi.org/10.1073/pnas.1618029113.

$\begin{array}{lll}\text { Türkiye } & \text { Sağlık } & \text { Bakanlığı. }\end{array}$ https,//covid19bilgi.saglik.gov.tr/depo/rehberler/COVID19_Rehberi.pdf?type=file (accessed date July 10, 2020).

Wang L, He W, Yu X, Hu D, Bao M, Liu H, Zhou J, Jiang H. 2020. Coronavirus disease 2019 in elderly patients, characteristics and prognostic factors based on 4-week follow-up. J Infect, 806: 639-645. https,//doi.org/10.1016/j.jinf.2020.03.019.

Wang Z, Yang B, Li Q, Wen L, Zhang R. 2020. Clinical Features of 69 Cases with Coronavirus Disease 2019 in Wuhan China. Infect Diseases Soc America, 7115: 769-777. https//doi.org/10.1093/cid/ciaa272.

WHO.2020.https,//www.who.int/emergencies/diseases/novelcoronavirus-2019accessed 10 July 2020

Wu CP, Adhi F, Highland K. 2020. Recognition and management of respiratory coinfection and secondary bacterial pneumonia in patients with COVID-19. Cleve Clin J Med, 87: 11 659-663. https,//doi.org/10.3949/ccjm.87a.ccc015.

Zhou F, Yu T, Du R, Fan G, Liu Y, Liu Z, Xiang J, Wang Y, Song B, Gu X, Guan L, Wei Y, Li H, Wu X, Xu J, Tu S, Zhang Y, Chen H, Cao B. 2020. Clinical course and risk factors for mortality of adult inpatients with COVID-19 in Wuhan China, a retrospective cohort study. Lancet London England, 39510229: 1054-1062. https,//doi.org/10.1016/S0140 67362030566-3v.

Zhu X, Ge Y, Wu T, Zhao K, Chen Y, Wu B, Zhu F, Zhu B, Cui L. 2020. Co-infection with respiratory pathogens among COVID2019 cases. Virus Res, 285: 198005. https,//doi.org/10.1016/j.virusres.2020.198005. 